\begin{tabular}{|l|l|}
\hline & $\begin{array}{l}\text { Academic } \\
\text { Journal of } \\
\text { Islamic Studies }\end{array}$ \\
& Institut Agama Islam Negeri (IAIN) Curup, Indonesia \\
ISSN 2580-3174, (p); 2580-3190 (e)
\end{tabular}

\title{
Interpretations of Verses about Islamic Criminal Law and its Polemics in Indonesia's Positive Law
} \author{
Hasep Saputra, Nurma Yunita, Ainal Mardhiaturrahman,
Wina Purnamasari \\ Institut Agama Islam Negeri (IAIN) Curup, Indoneisa \\ hasepsaputra01@gmail.com, nurmayunita@iaincurup.ac.id, \\ narendradhipalbh@gmail.com, winapurnamasari24@gmail.com
}

\begin{abstract}
This study was conducted to find out the interpretations of Islamic criminal law verses and to see the polemics which occurred in the applications of Islamic criminal law in Indonesia alongside the harmonization of its applications in Indonesia. This study used a normative-descriptive approach in a way that explained in detail the laws and the verses' interpretations as well as the polemics of Islamic criminal law in the Indonesia's positive law. In the context of the development and application of national law in Indonesia, Islamic law is one of the sources adopted. Islamic law itself regulates the vertical relationship with Allah and the relationship with humans. These two relationships have a role in the formation of national law in Indonesia. In terms of applications, Islamic law can contribute to the development of positive law with the following three alternatives: 1) Islamic law which is a continuation of legal politics in the colonial period, either through transitional rules of the 1945 Constitution's article 2 or by means of being stipulated in the further new legislation, 2) positive Islamic law which is sourced from Islamic values, and 3) the theory of legal leveling. This theory is applied to make Islamic law a source of national law in the future.
\end{abstract}

Keywords: Islamic Criminal Law; Positive Law; Legislation

\section{Introduction}

Islamic criminal law is based on the Qur'an and Sunnah, and it is important to examine how those of Mufasir explain Islamic criminal law. Islam is recorded as having entered the archipelago since the first century of hijriah passing along the coast of Sumatra, specifically in the Perlak area (East Aceh). Furthermore, Islam spread throughout the eastern archipelago. ${ }^{1}$ The spread of Islam in the Nusantara archipelago left behind Islamic culture and law that had

1 John Kenedi, "Penerapan Syariat Islam dalam Lintasan Sejarah dan Hukum Positif di Indonesia," Nuansa : Jurnal Studi Islam dan Kemasyarakatan 10, no. 1 (June 10, 2017), doi:10.29300/nuansa.v10i1.640. 
been ingrained in Indonesian society long before the Dutch arrived to colonize. $^{2}$

With the spread of Islam throughout the archipelago, Islamic law, which is the spirit of worship for Muslims, requires affirmation in order for Muslims to live peacefully in Indonesia. Sociologically, Islamic law reflects the values that Muslims hold in society, nation, and state life. ${ }^{3}$ Islamic law, which is dynamic and open, is thought to be capable of underpinning and directing the dynamics of social life in Indonesia, because Islamic law has two dimensions, namely: first, a dimension rooted in the qath'i argument. This first dimension is universal and applies throughout the ages, uniting Muslims all over the world. Second, the dimension of Islamic law that is rooted in Dzonni's argument and provides the possibility of epistemology of law and law enforcement for each region differs depending on conditions, sociology, situations, and history. ${ }^{4}$

Islamic law is still widely regarded as insufficient by bureaucrats, political elites, and legal experts, influencing public perceptions and causing polemics in Indonesian society, as evidenced by the numerous protests that occurred when Islamic criminal law was implemented in Aceh. According to the legality principle, Islamic criminal law is classified as unwritten law. In the fiqh literature, the term Islamic criminal law is more commonly known as ahkam al-jina'iyyah, which refers to the laws that govern the words, attitudes, or actions of mukallaf people in relation to various acts of violation or crime (Jarimah / jinayyah) by type. ${ }^{5}$

Autocratic states ruled by exclusives are resistant to change. As a result, they will tend to think conservatively about the law, viewing it only as a tool for maintaining security and order.

From historical data, it is not a taboo matter if we look at the history of the development of positive law in Indonesia which has never been separated from the 3 elements that are rooted in the pluralistic culture in Indonesia. The 3 elements are customary law, Islamic law and Dutch western inheritance law ${ }^{6}$

2 Ibid.

${ }^{3}$ Nur Kholis, "Prospek Penerapan Hukum Islam Di Indonesia," Al-Mawarid 8 (August 18, 2002): Hal. 48, doi:10.20885/almawarid.vol8.art12.

${ }^{4}$ Kholis, "Prospek Penerapan Hukum Islam Di Indonesia."

5 Syarif Hidayatullah, "Perkembangan Dan Eksistensi Hukum Pidana Islam Sebagai Sumber Hukum Di Indonesia," SANGAJI: Jurnal Pemikiran Syariah Dan Hukum 1, no. 2 (October 6, 2017): 245-63, doi:10.52266/sangaji.v1i2.206.

${ }^{6}$ Zaka Firma Aditya, "Romantisme Sistem Hukum di Indonesia: Kajian Atas Konstribusi Hukum Adat dan Hukum Islam Terhadap Pembangunan Hukum di 
as described in the Decree of the Indonesian People's Consultative Assembly No. IV / MPR-RI / 1999 concerning GBHN, CHAPTER IV, Policy Direction, point 2. It is stipulated that Islamic Law, Customary Law and Western Law are the sources of the formation of national law.

As the country with the world's largest Muslim population, Indonesia guarantees the legitimacy of the existence of religion in positive jurisdiction, as stated in Article 29 of the 1945 Constitution. ${ }^{7}$ Islamic law is a source of law for the formation of positive law in Indonesia, according to the preamble of the Constitution, article 29 paragraph (1) of the 1945 Constitution and its amendments, and Hazairin's interpretation of article 29 paragraph (1) of the 1945 Constitution. It is not permissible under Indonesian national law to enact legislation that violates Islamic law for Muslims or other religious laws in Indonesia. ${ }^{8}$ The foundation of the philosophy of Islamic religious law application is in accordance with the ideals of Indonesian law, namely Pancasila, and is clearly stated in the contents of the 1945 Constitution's preamble. ${ }^{9}$

We now know that, in addition to the applicable laws in the legislation originating from Dutch law, there are also customs and cultural roles that color our laws at this time, making it all a polemic when it comes to enforcing Islamic law at this time. It is undeniable that Islamic law has been recognized in our country, but it is only limited to civil matters such as marriage, inheritance, and other problems; it does not cover a higher social order such as crime and so on. However, there are two issues with upholding Islamic law:

First, there are issues concerning Islamic law's position in Indonesia as one of the recognized systems alongside customary law and western law.

Second, there is the internal problem of Islamic law as a norm that governs people's lives. Islamic law has influenced many national laws in Indonesia as part of the legal system.

Indonesia," Jurnal Rechts Vinding: Media Pembinaan Hukum Nasional 8, no. 1 (May 15, 2019): hal. 37, doi:10.33331/rechtsvinding.v8i1.305.

7 Dwiyana Achmad Hartanto, "Kontribusi Hukum Islam Dalam Pembaharuan Hukum Pidana Di Indonesia (Studi Pidana Cambuk Di Nanggroe Aceh Darussalam)," AlAhkam Jurnal Ilmu Syari'ah Dan Hukum 2, no. 2 (2016): hal. 2, http://ejournal.iainsurakarta.ac.id/index.php/al-ahkam/article/view/147.

8 Sularno, "Syari'at Islam dan Upaya Pembentukan Hukum Positif di Indonesia," Al-Mawarid 16 (2006): hal. 212, doi:10.20885/almawarid.vol16.art6.

${ }^{9}$ Rina Antasari, "Hukum Islam Dalam Ruang Sistem Hukum Di Indonesia," hal. 102, accessed May 6, 2021, http://jurnal.radenfatah.ac.id/index.php/istinbath/article/view/788. 
Dwiyana Achmad Hartanto has investigated the issue of Islamic law's contribution to the reform of criminal law in Indonesia; however, Dwiyana is limited to explaining the study of caning in Nanggroe Aceh Darussalam, as well as Syarif Hidayatullah, who investigates the development and existence of Islamic criminal law as a source of law in Indonesia. Syarif only explains how the development of Islamic criminal law in Indonesia. The authors also explain the interpretation of verses and the history of Islamic criminal law in Indonesia, and the authors also see how the polemics that arise when Islamic criminal law is applied in Indonesia.

\section{The History of Law in Indonesia}

Legal history is a method or science that is a branch of historical science (not a branch of law science), which studies, analyzes, verifies, interprets, compiles references (setting the clausule), and making tendencies, drawing certain conclusions (hypothetizing) about every fact, concept, organization, and rule relating to the law that has ever been applied.10

Sociologically, the existence of a National Law Politics is indeed a necessity immediately following Indonesia's independence, because the occurrence of independence resulted in a very revolutionary change in the ideals and realities of Indonesian society. If, prior to independence, Indonesian society's ideas and structures were based on very exploitative colonialism, these ideas and structures were completely transformed into an independent society after independence. 11

Given the development of the Indonesian national legal system, which is still trying to find a form or format that is in accordance with the spirit of the Proclamation and the values contained in the community, and not denying the enormous influence of other legal systems culturally and legally, it has its own consequences in the formation of society and the development of the nation. Of course, the development of national law must remain independent and consistent in running in accordance with the spirit of Pancasila and unity in diversity within the framework of fostering a national law that is in the midst of the vortex of another world legal system. The inclusion of other values that intentionally or unintentionally become a factor that influences or is influenced must be viewed as a whole, and can or does not give bad excess to the development of national law. Of course, the evolution of national law continues

10 Munir Fuady, Sejarah Hukum (Jakarta: Ghalia Indonesia, 2009), hal. 1.

22.

${ }^{11}$ Oksep Adhayanto, "Perkembangan Sistem Hukum Nasional" 4, no. 2 (2014): 
to provide a space for "community laws" to coexist with other modern legal systems. ${ }^{12}$

As a developing country, Indonesia clearly requires guidance and development of the National Legal System in order to encourage and support development in all fields. To borrow Roscoe Pound's phrase, "as a tool for social engineering," national law should be able to provide direction and a way for law, society, and the state to interact with one another. Of course, this is possible if the enthusiasm for fostering and developing national law is based on the spirit and values adopted in society, without ignoring other developed values that are in accordance with Indonesian society's culture. ${ }^{13}$

Seeing the face of Indonesian law that is still overshadowed by colonial law gives the impression that Indonesian law is not independent because it is still interdependent with the Dutch and French legal systems that form Indonesian law. As a result, in order to achieve the independence of Indonesian law, the development of the Indonesian legal system must be implemented as soon as possible.

Not only positive law, but also the recognition and enforcement of Islamic law in Indonesia shows its own historical path in the course of the Indonesian legal system. Both during the Dutch East Indies government's reign and after Indonesia's independence, there was a period when a view and recognition emerged, which was later manifested in various policies, regarding the position of Islamic law as law that stands on its own and is a law that truly lives in Indonesian society. There are also times when Islamic law is only seen as part of (perceived as part of) other laws, and thus Islamic law only has the power to apply if the other law truly wants it, which peaks when Islamic law is excluded from the legal system that exists. ${ }^{14}$ The emergence of such policies is not solely based on what occurs in society and as a form of reflection and what the majority of people actually want, but rather takes shape as a result of social construction created by some people, with the goal of achieving certain goals.

Efforts to'set aside' the existence of Islamic law in the legal systems of the Dutch East Indies and Indonesia were not solely based on considerations of

12 Ibid., hal. 209.

13 Ibid., hal. 210.

14 Tjun Surjaman, Hukum Islam Di Indonesia Perkembangan Dan Pembentukannya (Bandung: Remaja Rosdakarya, 1994), Hal. 101-102. 
the merits of the legal system when used to regulate the lives of the people, but rather demonstrated the political and economic aspects. ${ }^{15}$

According to the current state of affairs, civil law in Indonesia consists of: First, there is customary civil law, which is a set of legal provisions that govern relationships between individuals in customary communities based on individual interests. The people referred to here are the Indonesian nation's social groups. Customary civil law provisions are generally unwritten and are passed down through indigenous peoples' lives. Second, European civil law, which refers to the legal provisions that govern legal relations involving the interests of Europeans and those who are subject to these provisions. Third, there is a section of civil law that is national in nature, namely areas of civil law resulting from national products. Marriage law, as stipulated in Law Number 1 of 1974, and agrarian law, as stipulated in Law Number 5 of 1960, are examples of parts of national civil law that are made. 16

The period of law in Indonesia can be divided into four historical stages, namely the period of colonialism, the period of physical revolution to liberal democracy, the period of guided democracy to the New Order, and the period of the Reformation Era. The period of time can be described including:

1. The period of colonialism is divided into the following:

There are several historical periods of the development of Islamic law in Indonesia

a. The Vereenigde Oost Indie Compagnie (VOC) period

The Vereenigde Oost Indie Compagnie (VOC) period can be defined by the application of Dutch-centric laws with the primary goal of exploiting economically and as an effort to overcome the Dutch economic crisis, disciplining natives through authoritarian means, and providing protection for VOC employees, including European immigrants.

b. Dutch Liberal Period

In the Dutch Liberal period, under pressure from the liberal group in parliament, a grondwet (constitution) was stipulated in 1848 in the Netherlands, which ordered that all arrangements for the needs of the colonial government (including the state budget) must be made in the form of a law (wet). As a result, the Dutch central parliament was able to intervene in the

15 Sunaryati Hartono, Hukum Ekonomi Pembangunan Indonesia (Bandung: Binacipta, 1908).

16 Kartini Muljadi, Perikatan Pada Umumnya (Jakarta: Rajagrafindo Persada, 2003), hal. 2. 
Dutch colony's political-legal process. A regulation relating to governance (Dutch East Indies) was issued in 1854 as a development during this liberal era, providing legal protection for natives from the arbitrariness of the colonial government. This regulation imposes restrictions on the executive (particularly the President) and the police, including the availability of a free trial process. The Regering Reglement (abbreviated RR 1854) was intended to protect natives, but the primary goal was to protect the interests of private businesses in the colony. The economic and political crisis that occurred forced him to change his political and economic policies.

c. The period of ethical politics until Japanese colonialism

The ethical politics policy was an attempt by the Dutch East Indies government to Europeanize indigenous peoples. Initially, ethical politics related to legal reform were:

1) Education for indigenous children, including further legal education.

2) The formation of the Volksraad, as a representative institution for the natives, as a quasi-legislative in the colonial government.

3) Structuring government organizations, especially in terms of efficiency.

4) Structuring the judiciary in terms of professionalism.

5) Establishment of statutory regulations that are oriented towards legal certainty. The leaders of the state at the beginning of independence did not have enough time to build a legal order, so that through Article II of the Transitional Rules of the 1945 Constitution, the laws that were in effect at the time when Indonesia were not yet independent were enforced.

2. The period of physical revolution to liberal democracy

a. Period of physical revolution

The existing period of physical revolution did not provide much opportunity for the nation's leaders to change the law. At the start of this period, reforms in the field of justice were carried out with the goal of decolonization and nationalization, by continuing the unification of judicial bodies by simplifying, and by reducing and limiting the roles of customary and autonomous courts, with the exception of religious court bodies, which were strengthened with the establishment of the High Islamic Court.

b. Liberal democracy period

The period of liberal democracy, which began with the Provisional Constitution of 1945 and was progressive in terms of human rights recognition, legal reform, and judicial reform, did not see much progress. The dichotomy between law and customary courts in an effort to codify and unify 
into national law that can adapt to economic developments and the order of international relations is a stumbling block, making it difficult for politicians and judges to move and make reforms.

3. The period of guided democracy until the new order

a. Guided democracy period

The change from a parliamentary system of government to a presidential system, initiated through a Presidential Decree on July 5, 1959 to return to the 1945 Constitution. Efforts to abandon colonial laws that were liberal and foreign to smell made the face of legal institutions and judicial systems degenerate due to submission to the executive branch, corruption rampant in the judiciary starting from the police, prosecutors, court officials, judges and lawyers. Government steps in the dynamics of law and judicial institutions are:

1) Abolishing the doctrine of separation of powers, and the judiciary is under the executive branch.

2) The legal symbol of the goddess of justice is replaced by a banyan tree, which means protection.

3) Through Law no. 19 of 1964 and Law no. 13 of 1965 provided the possibility for the executive to interfere in the judicial process.

4) Civil law originating from the colonial period does not apply, only as a reference, so that judges are expected to develop decisions that are more situational and contextual.

b. New order period

The fall of the Old Order regime through its guided democracy, which was later replaced by the New Order, marked the role of the military, especially the army, which controlled the government, also assisted by liberal economists-technocrats. The New Order made its initial efforts by eliminating the law in the political and governmental process. The New Order suspended the implementation of Law no. 5 of 1960 concerning Basic Agrarian Basic Regulations (UUPA), and at the same time enacting laws that facilitate foreign investment in Indonesia, for example the Foreign Investment Law, the Forestry Law, and the Mining Law. The judiciary in the New Order era was not independent because it was under the influence of the government.

The New Order regime also did:

1) Submission of legal institutions to the executive

2) Control of the education system and the destruction of critical thinking, including legal thinking; 
Such policies seem to have continued after Indonesia's independence. Both during the reign of President Sukarno and President Suharto, as a result and mutual suspicion that occurred between Islam and the state, various aspects related to Islam, except that the ritual dimensions were always trying to be weakened and tamed, and never given the opportunity to exist, grew. and developing In such a macro context, then it can be understood, that even though during the Indonesian government Islamic law the position of Islamic law was recognized as a law that stood on its own strength, however, it seemed that it had not yet taken a proper place in the Indonesian legal system because the law Islam is "only" competent in an environment that is seen as nonneutral, namely issues that fall within the scope of family and inheritance law, with various variations of narrowing / limiting and expanding authority. ${ }^{17}$

The fall of the New Order was preceded by a monetary crisis and also by the pressure of the people to carry out social, economic, political reforms, as well as all areas of life in society that so far did not get the place they should have.

c. The post-New Order period (reform era)

The term Reformation was first used by Pope Gregory VII, to mean an attempt to reform. According to Soetandyo Wignojosoebroto, reform is not only interpreted as an attempt to reform, but as an effort to improve the order in the structure.

The objectives of reform are to improve the legal system, uphold the rule of law, and the political system in order to achieve the goals of the state as mandated in the constitution, namely to improve the welfare of a just and prosperous society.

1) The New Order built a monopolistic political system and maintained the status quo;

2) The New Order limited the number of political parties;

3) Maintaining an authoritarian bureaucracy;

4) Developing the economy of government and private economic clientelism;

5) Repress ideology and use authoritarian discourse.

Era of the Reformation On May 21, 1998, President Soeharto resigned and was replaced by Vice President BJ Habibie, the Reformation Era began. The background of President Soeharto's fall, namely the weakening of the

17 Bahtiar Effendy, Islam Dan Negara: Transformasi Pemikiran Dan Praktik Politik Islam Di Indonesia (Jakarta: Paramadina dan Yayasan Ibn Sina, 1998), hal. 3. 
Indonesian economy as a result of the Asian financial crisis, triggered a large amount of dissatisfaction with the government, leading to massive demonstrations by various student action organs in various regions of Indonesia. Changes such as the liberalization of political parties, the grant of press and opinion freedom, and the repeal of the Subversion Law are examples of such changes. The 1945 Constitution was amended four times; there was an update, namely:

1) Reforming the political system and state administration;

2) Reforming the legal system and human rights; and

3) Economic system reform.

4) ABRI is no longer part of the DPR, the DPD replaces regional and class delegates,

5) The formation of multi political parties;

6) The realization of the implementation of regional autonomy with an emphasis on the Tk region. II;

7) The MPR is only a meeting forum between the DPD and the DPR;

8) The President and Vice President are directly elected;

9) The establishment of new legal institutions such as the Constitutional Court, KPK and KY

\section{Interpretations of Islamic Criminal Law Verses}

The verses in Al-Qur'an surah Al-Maidah 33-38 explain Islamic criminal law. The Asbabun Nuzul of these verses tells the story of a group of people from 'Urainah who came to Medina and then became ill in the city of Medina. Then Rasulullah SAW sent an alms camel and instructed him (a group of people) to drink milk and urine from the camel sent by Rasulullah SAW, and they worked on it and became healthy as a result. However, they abruptly became apostates, killing the camel shepherd (as seen by Rasulullah's messenger) and stealing all of his property (including the camel). The Prophet then dispatched troops to follow in the footsteps of these people, and when they were apprehended, their hands were cut alternately, their eyes were plugged with nails, and they were thrown to death in a hot place. Then verse 33 appeared. ${ }^{18}$

Allah SWT told the story of Qabil and Abel, the two sons of Prophet Adam, and explained the cruelty of murder and tied him tightly so as not to hal. 493 .

${ }^{18}$ Muhammad Ali Ash-Shobuniy, Tafsir Ayat Ahkam (Jakarta: Bina Ilmu, n.d.), 
indulge in the desire to kill. Namely by saying: "whoever kills someone, as if he has killed many people".

So here Allah swt also wants to tell how the torture and punishment that are inflicted on people who riot on the surface of this earth, so that and as if no one else is braver than him. Then it also explained about the punishment for thieves as a form of tarnishing security on this earth, and is considered as one of the kinds of riots. Here Allah the Almighty imposes a very tight punishment between the punishment of theft and thieves with the sin of murder.

\section{The legal contents}

1. Crimes categorized as rogues, namely verses that clearly explain people who fight against Allah and His Messenger and do damage on this earth. And by taking the act of murder, cut off his hands and feet alternately, or crucified, and even exiled from the face of the earth (from where they live). The problem in this verse as Fuqaha argues is who is fighting against it?

a. According to Imam Malik, "fighters" are those who approach each other with weapons.

b. According to Imam Abu Hanifah, those who fight are those who carry weapons in the wilderness or in Udik (uninhabited). If this occurs, as it does in the city, assistance is still available.

c. According to Shafi'i, anyone who commits a major theft in the city is a fighter. The theft was either committed in a home or on the side of the road.

2. Some scholars argue: an imam (head) may carry out alternative punishments against the perpetrators of these crimes. With one of the punishments that Allah has ordained, for example: by being killed, crucified, alternating hands and feet cut off and exiled from the face of the earth (prison). Based on the dzahir verse "be killed, crucified, cut off hands and feet or exiled from the face of the earth".

While, Abu Hanifah brought this verse in the sense of takhyir (may choose), rather than Mutlaq for all those who fight, an imam (head) may choose an alternative punishment in four ways:

a. It is permissible to take the punishment by killing, cutting off the hands and feet alternately.

b. It is permissible to take the punishment of alternating arms and legs cutting and also crucifying them

c. It is permissible to just crucify without cutting off the hands and feet 
d. It is permissible to take the punishment of killing in accordance with the demands of benefit

3. The penalty of the cross technique. According to Jumhurul Fuqaha, an Imam may accept one of these punishments, such as being crucified. The crucifixion technique involves being crucified while still alive and being placed on the highway for a full day or three days to warn other criminals. After that, they were stabbed to death with a spear. That is the Malikiyah and Hanafiyahs' viewpoint. Meanwhile, Imam Syafi'i stated, "I do not want the criminal to be killed while being crucified," because the Prophet of Allah (saw) prohibited killing people by injuring them.

4. When the criminal has his hands cut off and the conditions for cutting off his hands.

Sarriqah (stealing) in Arabic is taking other people's property by stealth and by means of a tactic. While in the definition of syara 'which has been stipulated by the Fuqaha, is someone who is aware and has matured to take other people's assets in a certain amount hidden from his storage place. As for the number of stolen goods that were subject to the sanction of cutting off the hands, Fuqaha themselves still have conflicting opinions, including:

a. Abu Hanifah and Tsauri said: no cutting hands, but stealing over 10 dirhams or items valued above 10 dirhams

b. Malik and Syafi'I said: no cutting hands but stealing a quarter of a dinar or 3 dirhams.

The reasons are:

a. Abu Hanifah based on the words of the Holy Prophet "there is no cutting off the hand in matters less than 10 dirhams"19

b. Malikiyah and Syafi'iyah based on hadiths. In the history of Aisyah, ra she said: "The prophet PBUH cut off the hand of someone who stole items over a quarter of a dinar (3 dirhams)". (Narrated by Abu Daud and Tirmidhi $)^{20}$

And this is also narrated by Abu Bakr, Umar, and Ali rhm.

Imam Syafi'i said, Allah said, "the man who stole and the woman who stole, cut off both hands". Some think that prisoners and traffickers who steal can live freely without punishment. Even though you don't have any evidence,

${ }^{19}$ Nasbur rayah, oleh az-Zuaili. 3:355

20 Dalam Riwayat bukhari berbunyi sebagai berikut: " tangan pencuri itu dipotong karena mencuri seperempat dinar". 
either from the Qur'an, or from the ijma '. So you remove the punishment upon them and specialize them in this and nothing else. ${ }^{21}$

5. (Restriction of cutting off hands) according to the word of Allah SWT "then cut off their hands" clearly shows that the thief's hand must be cut off, and the Fuqaha have agreed that the hand that is cut off is the right hand. Because in one Qiro'ah Ibnu Mas'ud said: "Then cut off their right hand" Then the fuqaha also differed about the limitations of cutting off these hands. Among others are:

a. Fuqaha' Amshar said that cutting off the hand from the limit of the wrist, not from the limit of the elbow, nor from the limit of the armpit.

b. Al-khawarij said: limit the cut off of the hand to the armpit.

c. One group argued: the cut limit of the hand is only the fingers.

The reason for Jumhur is the history which says that the Prophet had cut off the hand of a thief from the wrist, likewise the history of Ali, Umar ibn Khattab ra.

\section{Islamic Criminal Law in Indonesian Positive Law}

In general, Islamic law governs a two-line relationship, namely the vertical relationship with Allah, known as hablumminallah, and the law that governs human relations, known as hablumminannas. Both play a role in the development of national law. ${ }^{22}$ This is due to the fact that many Islamic law values have been incorporated into positive national law in Indonesia. ${ }^{23}$

Since Indonesia's independence until now, several laws in Indonesia have contained values or originated from Islamic law. A concrete example is the Marriage Law No.1 of 1974, which reflects the aspirations and values of Islamic law, Compilation of Islamic Law based on Presidential Instruction No. 1 of 1991, Law Number 41 of 2004 concerning Waqf, Sharia Regional Regulations that do not contradict Islamic law. In the preceding context, an effort has been made to promote Islamic law as a form of law that is in line

21 Syaikh Ahmad Musthafa al-Farran, Tafsir Imam Al-Syafi'iy (Jakarta: AlMahira, 2008), hal. 340.

22 Ajub Ishak, "Posisi Hukum Islam dalam Hukum Nasional di Indonesia," Jurnal Al-Qadau: Peradilan dan Hukum Keluarga Islam 4, no. 1 (August 3, 2017): hal. 60, doi:10.24252/al-qadau.v4i1.5753.

23 Amir Syarifuddin, Meretas Kebeuan Ijtihad: Isu-Isu Penting Hukum Islam Kontemporer Di Indonesia (Jakarta: Ciputat Press, 2002), hal. 20. 
with the needs of the Indonesian population, which has a negative character as a majority population. ${ }^{24}$

In Islamic thought, there is no dichotomy between religion, law and the State. Prof. Dr. H. Muhammad Tahir Azhary, SH introduced a theory called "Concentric Circle Theory". The Concentric Circle is a unity between religion, law and the State, where the three are closely related. Religion as a core component in the deepest circle. Then followed by the law and the last circle is the State. 25

In concentric circles, religion is the main source of law so that the content of law has normative and moral values. Furthermore, the State is in the outer circle as the encompasser and container of religion and law. ${ }^{26}$

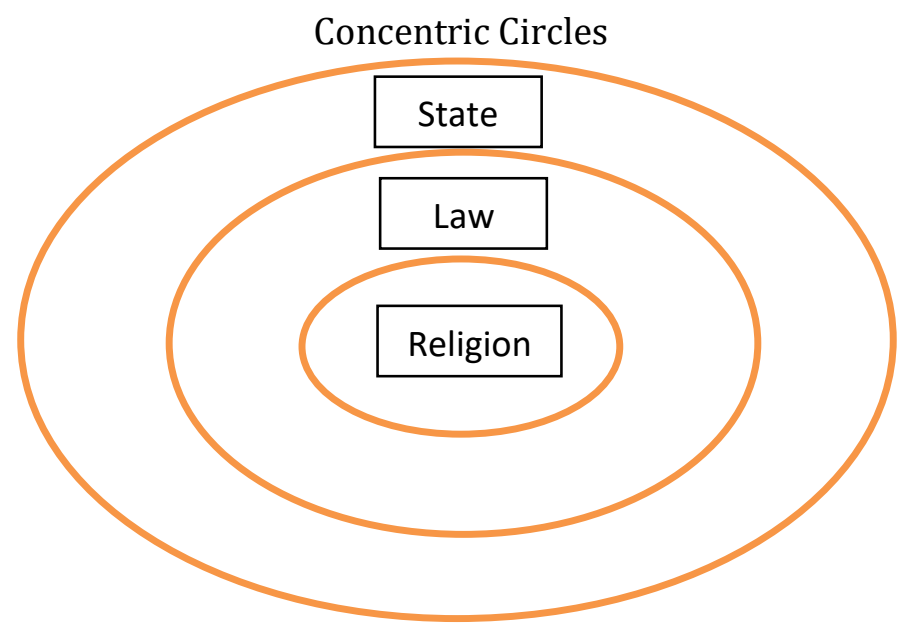

With the majority of the population's support and for other (historical and legal) reasons, Islamic law is positioned as an alternative to the formation of national law. As a result, a strategy or approach to upholding Islamic law is required for the transformation to be effective. The enforcement of Islamic law can be pursued through structural and cultural channels with the basic capital of a constitutional legal position. ${ }^{27}$

${ }^{24}$ Sohibul Itman, Positivisasi Hukum Islam Di Indonesia (Ponorogo: STAIN Poo Press, n.d.), hal. 4.

25 Muhammad Tahir Azhary, Negara Hukum (Suatu Studi Tentang PrinsipPrinsipnya Dilihat Dari Segi Hukum Islam, Implementasinya Pada Periode Negara Madinah Dan Masa Kini) (Jakarta: Prenada Media, 2003), hal. 67.

26 Ibid., hal. 68.

27 Abdurrahman Wahid, Kontroversi Pemikiran Islam Di Indonesia (Bandung: Remaja Rosdakarya, n.d.), hal. 203. 
The transformation through the supra-political structure is carried out in accordance with Indonesia's existing governmental lines. The legislative, executive, and judicial branches of government are all involved in the administration of the law. Transformation of the political infrastructure is carried out by optimizing and maximizing the role of existing political parties as well as structurally based Islamic organizations such as the Indonesian Ulama Council (MUI). In order to be implemented, systematic Islamic values must be translated into legal language in a predetermined pattern. As a result, what appears to be applicable and rational Islamic law. If Islamic law is made into statutory regulations, all that remains is to write it in the legal language in accordance with the applicable provisions.

The cultural path is followed by cultivating Islamic values as a life regulator. This culture aspires to give these values binding power. Islamic organizations such as Nahdlatul Ulama, Muhammadiyah, Islamic Unity, and others can play this role. The efforts of Islamic social organizations are realized through teaching, fatwas, and other forms of social action. This type of instruction is provided through both formal and informal education. ${ }^{28}$ Fatwas issued by social organizations such as MUI, NU, Muhammadiyah, Persis, and others. ${ }^{29}$ The development of Islamic law in this form is effective and practical for those who require it, including government officials, religious leaders, and community members. At the very least, this fatwa will serve as a reference for the practical application of Islamic law.

Thus, one of the positive aspects of Islamic law is the enforcement of Islamic law, which aims to ground Islamic law in the realities of community life. Inadvertently, an Islamic community has been formed by adopting Islamic values and principles as habits and customs. This means that people's legal awareness of the importance of Islamic values has been reflected in their behavior during social interaction and communication. This condition is very effective in supporting efforts to positively impact Islamic law, because the implementation of a perpu must also take into account the community's aspirations, which can be seen in the values that are developed and practiced. Furthermore, public legal awareness can be used as a bargaining chip by the government when developing new legal policies. ${ }^{30}$

${ }^{28}$ A Maltruf Siraj, Pembaruan Hukum Islam Di Indonesia (Yogyakarta: Pustaka Ilmu, 2012), hal. 132.

29 Ibid.

30 Padmo Wahyono, Indonesia, Negara Berdasar Atas Hukum (Jakarta: Ghalia Indonesia, 1986), hal. 143. 
In a later stage, a legal system and a national legal system will be established that are in accordance with Islamic principles (though not labeled as Islamic), or are not contrary to Islamic law. If the aforementioned issues are overcome and resolved, the transformation of Islamic law into national law will be completed. This is because there are no significant institutional barriers. The state fully guarantees the position of Islamic law in Indonesia, both through an ideal foundation, namely Pancasila, and a structural basis, namely the 1945 Constitution.

\section{Prospective Application of Islamic Law in Positive Law Reformulation in Indonesia}

Regarding the existence of the role of Islamic law, it can be explained by theoretical theories as follows: ${ }^{31}$

1. Receprti in Complexu theory, for adherents of Islam to fully apply Islamic law because they have embraced Islam even though there are deviations in its implementation.

2. Receptie theory, for indigenous people basically customary law applies. Islamic law applies Islamic legal norms if it has been accepted by the community as customary law.

3. The Receptie Exit Theory, Indonesia is obliged to form national law based on religious law.

4. Receptio a Contrario Theory:

a. For Muslims, Islamic law applies

b. This is in accordance with the beliefs and ideals of law, mental and moral ideals

c. Customary law applies to Muslims if it does not conflict with Islamic law.

5. Recoin Theory (Receptio Contextual Interpretio), applying Islamic law requires contextual interpretation of the text of the verses of the Qur'an.

From some of the above theories, we can observe that Indonesia still adheres to the Receptie Exit theory. This is because in developing the application of Islamic law in Indonesia, Muslims are faced with positive Islamic law which is limited to laws that apply to all Indonesian citizens which do not contradict the ideology of Pancasila and the Constitution. The concrete examples are still limited to mu'amalah matters in civil law.

31 Afdol, Kewenangan Pengadilan Agama Berdasarkan UU No. 3 Tahun 2006 Legislasi Hukum Islam Di Indonesia (Surabaya: Airlangga University Press, 2006), hal. 44. 
Islamic law can contribute to the development of positive law with 3 alternatives, namely: ${ }^{32}$

1. Islamic law is a continuation of legal politics from the colonial period, either through the transitional rules of Article 2 of the 1945 Constitution or as new laws and regulations. This alternative still emphasizes the distinctions between legal systems, such as Western law, Islamic law, and customary law. The area covered by Islamic law is civil law, with the institution being a Religious Court. This alternative produces "Islamic positive law," which is the material law or substance law of the Religious Courts that applies to the Islamic Religious Courts.

2. Islamic positive law based on Islamic religious values. The path forward from this alternative is for Muslims to formulate Islamic law principles and incorporate them into the formulation of positive law. As a result, the scope of Islamic law in positive law extends beyond civil law (family law) and into criminal law, constitutional law, and state administrative law. Islamic law will truly become a source of positive national law if it is oriented in this manner.

3. The theory of legal leveling, which is being used to make Islamic law a source of national law in the future. The values in the Holy Qur'an that are universal as abstract norms and legal ideals are used to describe the legal level. In conclusion, it can be stated that Islamic values and principles are infused into positive law.

In practice today, the applicable Islamic law is still limited to civil law. Efforts to positivasize Islamic law need to be fought for so that Islamic law can spread within the scope of crime, state administration and state administration. Positivization Islamic law can realize the ideals of Islam in the State as a State Baldatun Toyyibatun wa Rabbun Ghafur. Islamic law must show its existence that Islam is Rahmatan lil Alamin and prioritizes mashalih alummah. 33

According to Arifin, the sociological positivization of Islamic law is a socio-legal symptom of Dutch legal politics' long clash of three legal systems: customary law, western law, and Islamic law. Philosophically normative is an

32 Hartanto, "Kontribusi Hukum Islam Dalam Pembaharuan Hukum Pidana Di Indonesia (Studi Pidana Cambuk Di Nanggroe Aceh Darussalam)," hal. 185.

33 Khisni, Transformasi Hukum Islam Ke Dalam Hukum Nasional (Studi Ijtihad Hakim Peradilan Agama Tentang Pengembangan Hukum Kewarisan Dalam Kompilasi Hukum Islam Dan Kontribusinya Terhadap Hukum Nasional) (Semarang: Uninsula Press, 2011), hal. 3. 
attempt to clear up misconceptions about the continuity of Islamic law that have arisen since the 10th century Hijriah as a result of Islam's influential political upheaval in Indonesia. According to Arifin, Islamic law is thought to be capable of delivering prosperity in the afterlife and triggering the awakening of Indonesia, which has been politicized by Dutch law through the theory of Receptio In Complexu by engineering scientific law through the theory of Receptio In Complexu. As a result, positivization of Islamic law can become a form of embodiment of positive law that applies in accordance with national law awareness and societal conditions that necessitate reformulation of national law in accordance with the character of the Indonesian nation, which is pluralist in diversity. ${ }^{34}$

\section{The Application of Islamic Law in Indonesian Positive Law}

When it comes to the relationship between religion and state, Indonesia is a country that follows a symbolistic paradigm. Indonesia must accommodate the evolution of ideas that seek to incorporate Islamic legal values into positive law. When there is a demand to enforce positive law, Indonesia should not refuse outright. Nonetheless, the incorporation of sharia values into positive law must be done in accordance with science in the discipline of law and in accordance with the democratic process, rather than indoctrination.

Essentially, Islamic law has been applied indirectly. Islamic law itself has two, namely Islamic law that applies normatively and Islamic law that applies juridically. The normative itself is Islamic law, which deals with the relationship between humans and God, and whose sanctions take the form of social or social sanctions. While legal is what governs the relationship between humans and other humans and objects in society, Indonesia has accommodated this in several laws.

Before being positivated, Islamic law is basically included in the category of living law (labendes recht / living law), which is the law that is generally used to prevent cases from arising and when cases arise, these laws are used to settle the case without the help of advice from state legal institutions (Cotterral, 2012: 38). So whether we realize it or not, Islamic law has been widely accepted by the Indonesian people without coercion from the ruling party, even though this law has been positivated or not. So that the government's move to accommodate this law as positive law so that it can be valid in the state administration is of course also the right thing and can be accepted by the public. As long as the government is consistent with this and

\footnotetext{
${ }^{34}$ Sohibul Itman, Positivisasi Hukum Islam Di Indonesia, hal. 13.
} 
does not need to be studied with several protracted considerations, it is time for the Indonesian government to innovate according to the conditions in Indonesia.

The application of Islamic law material in Indonesian positive law is based on the provisions of the constitution, namely the first principle which reads "God Almighty". It is also stated in article 29 of the Constitution of the Republic of Indonesia, article 29 paragraph (1), namely "The State Based on One Godhead" and paragraph (2), namely "The State guarantees the freedom of each resident to embrace their respective religions and worship, according to religion and belief"

These two things demand that the National law be based on the one and only Godhead. ${ }^{35}$ This has become the main ideology in the formation of laws and regulations relating to the material of Islamic law because Pancasila and the constitution are the highest laws in the legal hierarchy in Indonesia.

This is reinforced by the existence of the principle of enactment of a law in Indonesia which reads "lex superior derogate legi inferior" which means that higher legislative regulations must be prioritized and can override lower legislative regulations. Thus, this provision provides an opportunity for the material of Islamic law to enter into the realm of positive law because the main law is an almighty divinity, which is emphasized again by the provisions of Article 29 paragraph (2) of the 1945 Constitution. academic formulation of laws that adopt the material value of Islamic law. This is because the interpretation can be used as a legal basis for the application of Islamic legal material in Indonesia.

In principle, one of the principles for the enforcement of laws in Indonesian positive law is Law Number 7 of 1989 which has been amended by Law Number 3 of 2006 and the second amendment has been amended by Law Number 50 of 2009, Law Number 7 of 1989 concerning Religious Courts was enacted and promulgated in Jakarta on December 29, 1989 (State Gazette of the Republic of Indonesia Year 1989 Number 49, Supplement to State Gazette of the Republic of Indonesia Number 3400).

Law No. 7 of 1989 concerning the Religious Courts, the aims and objectives of enacting them and their benefits include: 36

35 Ishak, "Posisi Hukum Islam dalam Hukum Nasional di Indonesia," hal. 60.

36 Anshoruddin, Prospektif Hukum Islam Di Indonesia (Pelembagaan, Perubahan Dan Prospektif), n.d., hal. 8-10. 
1. Confirming the status of the position and authority of the Religious Courts as part of the executing of the judicial power in the Republic of Indonesia.

2. Creating a legal entity / union of the Religious Courts as referred to in letter (d) of the preamble, considering law no. 07 of 1989 which states "that the arrangements regarding the composition, power and law by the Court in the Environment of the Religious Courts which so far are still varied".

3. Clarifying, emphasizing and perfecting the role, function and structure of the Religious Courts.

4. Is an important milestone for Muslims.

5. Religious Courts have become independent / equal courts.

6. Protection of women can be improved by giving equal rights to wives in defending their interests.

7. The development of a National Law with an Archipelago Concept and at the same time with the concept of Bhinneka Tunggal Ika in the form of the Law on Religious Courts.

8. Through jurisprudence, efforts to further strengthen the exploration of various principles of Islamic law as one of the raw materials in the preparation and fostering of National Law.

Principles of Law No. 7 of 1998, among others:

1. Religious Courts are State Courts (article 2 paragraph (3) of Law No. 48/2009, Article 2 of Law No. 7/1989).

2. Religious Courts are Courts for people who are Muslim (article 1 paragraph (1) of Law No. 7/1989).

3. Religious Courts stipulate and enforce laws for justice based on Pancasila (article 2 paragraph (2) Law No. 48/2009).

4. Religious Courts examine, decide and settle cases based on Islamic Law (article 49 and general explanation of Law No. 7/1989).

5. Justice is carried out for the sake of justice based on the one and only Godhead (article 2 paragraph (1) Law No. 48/2009) and article 57 paragraph (1) of the Law. No. 7/1989).

6. The trial is conducted in a simple, fast and low cost (article 2 paragraph (4) Law No. 48/2009, article 57 paragraph (3) Law No. 7/1989).

7. The judiciary is conducted according to the law and does not differentiate between people (article 4 paragraph (1) Law No. 48/2009, article 58 paragraph (1) Law No. 7/1989).

8. The judiciary is conducted free of influence and interference from outside, solely for the realization of truth and justice through law enforcement (article 3 paragraph (2) Law No. 48/2009).

\section{Law Number 7 of 1989 as amended by Law Number 3 of 2006}


The provisions of article 49 of the Republic of Indonesia Law No. 7 of 1989 Concerning Religious Courts has been amended by Law no. 3 of 2006, so that it reads as follows: The Religious Court has the duty and authority to examine, decide, and resolve cases of first degree between people who are Muslim in the field of marriage, inheritance, will, grant, waqf, zakat, infaq, sadaqah, syari'ah economics

The provisions of article 50 are amended to read as follows:

1. In the event of a dispute over property rights or other disputes in the case as referred to in Article 49, especially regarding the object of the dispute, it must be decided first by the Court in a general court.

2. In the event of a dispute over property rights as referred to in paragraph (1) whose legal subject is between people who are Muslim, the object of the dispute shall be decided by the Religious Court together with the case referred to in Article 49.

Between article 52 and article 53 a new article is inserted, namely article 52, which reads as follows:

Article 52 A: The Religious Court provides testimony from Rukyat Hilal in determining the start of the month in the Hijri year

Elucidation of Article 49: Dispute resolution is not only limited to the field of Shari'ah Banking, but also in other areas of Shari'ah Economics. What is meant by "between Muslim people" includes persons or legal entities which automatically submit themselves voluntarily to Islamic law regarding matters which fall under the authority of the Religious Courts in accordance with the provisions of this article.

\section{UU no. 1 of 1974 concerning Marriage}

This law regulates all forms of marriage, including the legal requirements of marriage, marriage procedures, minimum marriage limits, marriage permits and so on which are related to marriage.

\section{Law 16 of 2019 concerning Amendments to Law 1 of 1974 concerning Marriage}

This amendment to the law concerns the minimum age limit for marriage, which is in article 7 . The following amendments to the article:

Article 7

1. Marriage is only permitted if the male has reached the age of 19 (nineteen) years and the female has reached the age of 16 (sixteen) years. 
2. In case of deviation from paragraph (1) of this article, dispensation may be requested from the court or other official appointed by both parents of the male and female parties.

3. The provisions regarding the condition of one or both parents mentioned in Article 6 paragraph (3) and (4) of this Law shall also apply in the case of a request for dispensation in paragraph (2) of this article without prejudice to what is meant in Article 6 paragraph (6).

After the change:

\section{Article 7}

1. Marriage is only permitted if the man and woman have reached the age of 19 (nineteen) years.

2. In the event of deviation from the age requirement as referred to in paragraph (1), the parents of the male and / or the parents of the female party may request dispensation to the Court on very urgent grounds accompanied by sufficient supporting evidence.

3. The dispensation by the Court as referred to in paragraph (2) shall be obliged to listen to the opinions of the two prospective brides who are getting married.

4. The provisions regarding the condition of one or both of the prospective bride's parents as referred to in Article 6 paragraph (3) and paragraph (4) shall also apply to the provisions regarding the request for dispensation as referred to in paragraph (2) without prejudice to the provisions referred to in Article 6, paragraph (6).

\section{Conclusion}

According to the above description, the law in Indonesia also follows Islamic law, but it is only applicable to mu'amalah affairs in civil law. When Islamic criminal law is used in Indonesia, a debate ensues. According to the Mufasirs' interpretations of the verses relating to Islamic criminal law, Islamic law is appropriate to be applied in Indonesia, and it is not limited to the law of marriage and muamalah.

Indonesia continues to believe in the Receptie Exit theory. This is due to the fact that, in developing the application of Islamic law in Indonesia, Muslims are confronted with positive Islamic law, which is limited to laws that apply to all Indonesian citizens and do not contradict Pancasila's ideology or the Constitution.

In terms of implementing Islamic Law, there are three options: Islamic Law, which is a continuation of legal politics during the colonial period, either 
through the transitional rules of Article 2 of the 1945 Constitution or which is then poured into new legislation, positive Islamic law which is based on Islamic religious values, and the theory of legal leveling which is used to make Islamic law a source of national law in the future.

\section{References}

A Maltruf Siraj. Pembaruan Hukum Islam Di Indonesia. Yogyakarta: Pustaka Ilmu, 2012.

Abdurrahman Wahid. Kontroversi Pemikiran Islam Di Indonesia. Bandung: Remaja Rosdakarya, n.d.

Adhayanto, Oksep. "Perkembangan Sistem Hukum Nasional" 4, no. 2 (2014): 22.

Aditya, Zaka Firma. "Romantisme Sistem Hukum di Indonesia: Kajian Atas Konstribusi Hukum Adat dan Hukum Islam Terhadap Pembangunan Hukum di Indonesia." Jurnal Rechts Vinding: Media Pembinaan Hukum Nasional 8, no. 1 (May 15, 2019): 37. doi:10.33331/rechtsvinding.v8i1.305.

Afdol. Kewenangan Pengadilan Agama Berdasarkan UU No. 3 Tahun 2006 Legislasi Hukum Islam Di Indonesia. Surabaya: Airlangga University Press, 2006.

Amir Syarifuddin. Meretas Kebeuan Ijtihad: Isu-Isu Penting Hukum Islam Kontemporer Di Indonesia. Jakarta: Ciputat Press, 2002.

Anshoruddin. Prospektif Hukum Islam Di Indonesia (Pelembagaan, Perubahan Dan Prospektif), n.d.

Bahtiar Effendy. Islam Dan Negara: Transformasi Pemikiran Dan Praktik Politik Islam Di Indonesia. Jakarta: Paramadina dan Yayasan Ibn Sina, 1998.

Hartanto, Dwiyana Achmad. "Kontribusi Hukum Islam Dalam Pembaharuan Hukum Pidana Di Indonesia (Studi Pidana Cambuk Di Nanggroe Aceh Darussalam)." Al-Ahkam Jurnal Ilmu Syari'ah Dan Hukum 2, no. 2 (2016). $\quad$ http://ejournal.iainsurakarta.ac.id/index.php/alahkam/article/view/147.

Hidayatullah, Syarif. "Perkembangan Dan Eksistensi Hukum Pidana Islam Sebagai Sumber Hukum Di Indonesia." SANGAJI: Jurnal Pemikiran Syariah Dan Hukum 1, no. 2 (October 6, 2017): 245-63. doi:10.52266/sangaji.v1i2.206. 
Ishak, Ajub. "Posisi Hukum Islam dalam Hukum Nasional di Indonesia." Jurnal Al-Qadau: Peradilan dan Hukum Keluarga Islam 4, no. 1 (August 3, 2017): 57. doi:10.24252/al-qadau.v4i1.5753.

Kartini Muljadi. Perikatan Pada Umumnya. Jakarta: Rajagrafindo Persada, 2003.

Kenedi, John. "Penerapan Syariat Islam dalam Lintasan Sejarah dan Hukum Positif di Indonesia." Nuansa: Jurnal Studi Islam dan Kemasyarakatan 10, no. 1 (June 10, 2017). doi:10.29300/nuansa.v10i1.640.

Khisni. Transformasi Hukum Islam Ke Dalam Hukum Nasional (Studi Ijtihad Hakim Peradilan Agama Tentang Pengembangan Hukum Kewarisan Dalam Kompilasi Hukum Islam Dan Kontribusinya Terhadap Hukum Nasional). Semarang: Uninsula Press, 2011.

Kholis, Nur. "Prospek Penerapan Hukum Islam Di Indonesia." Al-Mawarid 8 (August 18, 2002). doi:10.20885/almawarid.vol8.art12.

Muhammad Ali Ash-Shobuniy. Tafsir Ayat Ahkam. Jakarta: Bina Ilmu, n.d.

Muhammad Tahir Azhary. Negara Hukum (Suatu Studi Tentang PrinsipPrinsipnya Dilihat Dari Segi Hukum Islam, Implementasinya Pada Periode Negara Madinah Dan Masa Kini). Jakarta: Prenada Media, 2003.

Munir Fuady. Sejarah Hukum. Jakarta: Ghalia Indonesia, 2009.

Padmo Wahyono. Indonesia, Negara Berdasar Atas Hukum. Jakarta: Ghalia Indonesia, 1986.

Rina Antasari. "Hukum Islam Dalam Ruang Sistem Hukum Di Indonesia." Accessed May 6, 2021. http://jurnal.radenfatah.ac.id/index.php/istinbath/article/view/788.

Sohibul Itman. Positivisasi Hukum Islam Di Indonesia. Ponorogo: STAIN Poo Press, n.d.

Sularno. "Syari'at Islam dan Upaya Pembentukan Hukum Positif di Indonesia." Al-Mawarid 16 (2006). doi:10.20885/almawarid.vol16.art6.

Sunaryati Hartono. Hukum Ekonomi Pembangunan Indonesia. Bandung: Binacipta, 1908.

Syaikh Ahmad Musthafa al-Farran. Tafsir Imam Al-Syafi'iy. Jakarta: Al-Mahira, 2008.

Tjun Surjaman. Hukum Islam Di Indonesia Perkembangan Dan Pembentukannya. Bandung: Remaja Rosdakarya, 1994. 